\title{
Bruno Leoni’s Legacy and Continued Relevance
}

\author{
Todd Zywicki*
}

George Mason University School of Law

\begin{abstract}
In his famous book Freedom and the Law, originally published in 1961, Italian lawyer and economist Bruno Leoni asked whether, over the long run, a society and legal system premised primarily on legislative lawmaking could sustain a system of individual liberty, or whether such a system required a common-law-style foundation to support it. In this article, I evaluate Leoni's challenge and find that his predictions about the nature of a legislative-centered legal system not only are more relevant than ever, but that recent tendencies toward extreme and arbitrary law-making by executive edict are consistent with the trends and intellectual principles that Leoni identified more than fifty years ago. Because modern legal developments reflect the working out of the jurisprudential principles that Leoni identified fifty years ago, Leoni's warnings are more relevant today than ever before.
\end{abstract}

JEL Codes: B3, K00, K1

Keywords: Bruno Leoni, F. A. Hayek, common law, legislation, spontaneous order, judicial process

\section{Introduction}

This year might have been Bruno Leoni's 101st but for his tragic murder in 1967. Leoni was an Italian lawyer-cum-academic who was one of Europe's leading classical liberal thinkers in the postwar era. Friend to the leading classical liberals of the age-including F. A. Hayek, James M. Buchanan, and Armen Alchian-Leoni was not

\footnotetext{
* I would like to thank Liberty Fund for its support; Alberto Mingardi, Richard Reinsch, and Jeremy Shearmur for comments; and Chaim Mandelbaum for research assistance. This article is adapted from Todd Zywicki, "When Friedrich Hayek Met Bruno Leoni," published July 17, 2014, at the Library of Law and Liberty website.

1 Leoni, as an attorney, looked after the interests of a friend's family. Leoni discovered that one of his friends' employees was stealing from his friend. On the evening of November 21, 1967, he went to see the employee and told him to return the money or be denounced. The employee responded by killing Leoni. "L'incredibile storia di Bruno Leoni raccontata da sua figlia Didi" ["The incredible story of Bruno Leoni told by his daughter Didi”], in Il Foglio, November 30, 2007.
} 
only a pioneer of law and economic thought but also an early adopter of public choice theory (Kemp 1990). However, Leoni's legal philosophy is largely ignored today.

To examine Leoni's continuing relevance to the law, I would like to consider a claim he makes in the introduction to his 1961 book Freedom and the Law: "My earnest suggestion is that those who value individual freedom should reassess the place of the individual within the legal system as a whole. It is no longer a question of defending this or that particular freedom-to trade, to speak, to associate with other people, etc.; nor is it a question of deciding what special 'good' kind of legislation we should adopt instead of a 'bad' one. ... It is a question of deciding whether individual freedom is compatible in principle with the present system centered on and almost completely identified with legislation. This may seem like a radical view; I do not deny that it is. But radical views are sometimes more fruitful than syncretistic theories that serve to conceal the problems more than to solve them" (Leoni 1991, p. 11; emphasis original).

This article takes up Leoni's radical challenge and asks: Is individual freedom compatible in principle with a legislation-centered system? Even more so, is individual freedom compatible with a system centered on executive fiat ("rulemaking" hardly being an accurate term to capture the arbitrary edicts emanating from the executive branch today)?

The essence of Leoni's argument lies in the contrast between lawmaking by legislatures versus lawmaking via a common-law-like process, which he describes broadly as "judicial decisions, the settlement of disputes by private arbiters, conventions, customs, and similar kinds of spontaneous adjustments on the part of individuals" (Leoni 1991, p. 7). In articulating this understanding of law, Leoni anticipates the arguments made by Hayek in Law, Legislation and Liberty ("LLL") a decade later. Leoni and Hayek's approaches consider common law as a spontaneous-order process, as distinguished, for example, from other philosophies that see the common-law process through a lens of legal positivism, effectively treating judges as functionally equivalent to legislators. In fact, there is more than just a similarity between Leoni's and Hayek's thinking on this point; it appears that it was Leoni that introduced Hayek to the common law, which then became the heart of LLL (Shearmur 1996, p. 88). In so doing, of course, Leoni also introduced Hayek to his distinctive interpretation of the common law as an alternative to the modern realist-positivist view. Indeed, the novelty of the focus on 
the common law in LLL is striking. The common law gets very little mention in either The Road to Serfdom (Hayek 1944) or The Constitution of Liberty (Hayek 1960), both of which focus on the formalist Rechtsstaat notion of the rule of law. Then, the common law appears full blown in LLL, with virtually no prior mention, and with a clear similarity to Leoni's version (Hayek 1973).

What happened during the period between The Constitution of Liberty and Law, Legislation, and Liberty to transform Hayek's thinking so dramatically? By all indications, the intellectual change comes from a single, identifiable influence: Hayek met Leoni, and Leoni inculcated in him the importance of the common law. ${ }^{2}$ In Freedom and the Law, Leoni grounds his understanding of law in his interpretation of the Roman jurisconsult. He compares the lawmaking process by the Roman jurisconsults to the common-law judge that Hayek describes in LLL. Indeed, Leoni uses the Roman law made by the jurisconsults and English common law essentially interchangeably as an analytical matter, so that the structure he uses in describing Roman law developed by the jurisconsult is essentially the same one that Hayek later identifies as distinctive in the common-law process under the English common law.

Law, for Leoni, as made by the jurisconsults and the commonlaw judges, is a spontaneous-order process focused on how the law emerges from the resolution of discrete disputes between private individuals and an ongoing conversation among different judges to determine what the law should be. As Leoni writes, "the whole process can be described as a sort of vast, continuous, and chiefly spontaneous collaboration between the judges and the judged in order to discover what the people's will is in a series of definite instances - a collaboration that in many respects may be compared to

\footnotetext{
2 "The change in Hayek's views can in my view be best seen as a result of the impact of Bruno Leoni" (Shearmur 1996, p. 88). Or, more precisely, Leonard Liggio and Tom Palmer observe that Hayek's ideas on the nature of spontaneous order influenced Leoni, and Leoni in turn influenced Hayek in analyzing the common law as a spontaneous order (Liggio and Palmer 1988, p. 716, n. 11). Hayek and Leoni first met at the University of Chicago in 1953 (Hayek 1968). In a letter from Hayek to Leoni written April 4, 1962, Hayek says that he not only enjoyed Freedom and the Law, but that it had given him new ideas (Shearmur 1996). It appears that Hayek did not attend Leoni's lectures at the Freedom School in 1958 but read Freedom and the Law when those lectures were transcribed and became the basis for the book. Liggio and Palmer report that Hayek discussed Leoni's ideas at a seminar at the University of North Carolina in 1959, shortly before The Constitution of Liberty was published (Liggio and Palmer 1988, p. 716, n .11).
} 
that existing among all the participants in a free market" (1991, p. 22).

For Leoni, the significance of Roman law (and later English common law), and its unique compatibility with individual liberty, stems from distinctive characteristics of the common law that are lacking in the legislative process. At the heart of his model is the importance of what he calls "law as individual claim." What does he mean by that, and why is it significant?

\section{Common-Law Liberty}

For Leoni, the idea of "law as individual claim" means that the law essentially leaves individuals alone, unless two private citizens seek intervention by a judge to resolve a dispute between them. That particular ruling is technically applicable only to those two parties (although by the force of precedent, it may potentially be invoked by other parties as applicable to their situations). He states, "Judges or lawyers or others in a similar position are to intervene only when they are asked to do so by the people concerned ... [and] the decision of judges is to be effective mainly in regard to the parties to the dispute, only occasionally in regard to third persons, and practically never in regard to people who have no connection with the parties concerned" (1991, p. 22).

Thus, you can go about your business, and if everything works satisfactorily, you never have to call in the state. What this means, Leoni observes, is "that the authors of these decisions have no real power over other citizens beyond that which those citizens themselves are prepared to give them by virtue of requesting a decision in a particular case."

What about precedent? Doesn't the rendering of a decision by one judge mean that the resolution of a dispute does, in fact, impact and bind third parties through an obligation of other judges to apply the same principle to later cases? Not as Leoni sees it. Embedded in the traditional common law-and economists Robert Staaf and Louis De Alessi later developed this idea ${ }^{4}$-is the ability of private parties

\footnotetext{
3 This view was developed by Leoni in lectures given at the Freedom School Phrontistery in Colorado Springs, Colorado, December 2-6, 1963. Although not included in the original edition of Freedom and the Law, it was added in the third edition along with several other previously unpublished lectures.

${ }^{4}$ De Alessi and Staaf $(1989,1991)$ argue that the virtue of the common law is not that it promotes efficiency, but rather that it provides parties with a stable
} 
to contract around the common-law rules. Thus, the whole point of common-law rules is that they are there for private parties to use to coordinate their affairs, but where the rules are not useful to that end, the parties are at liberty to ignore them and create their own rules by contracting around them. This explanation is the essence of his idea that the common law is a "spontaneous order" analogous to the market process: there is sort of back-and-forth collaboration between individuals asserting individual claims and judges resolving those claims and improving the law to better meet specific demands. In turn, those resolutions feed back into individuals' decision-making and either promote or undermine private expectations and private ordering. Moreover, judges can be seen as entrepreneurs, proposing different rules in order to see which rules fit individual expectations most efficaciously. ${ }^{5}$ From this enterprise of private, uncoordinated litigants seeking to vindicate their individual claims, an entire legal system springs up. Under the common law, the judges played the key role; for Leoni, it was the jurisconsult under the Roman law who performed that function.

Legislation, by contrast, is enforced on everyone, whether they like it or not, and legislative commands are binding regardless of whether they are sensible, persuasive, or conducive to the needs of those bound by it (Leoni 1991, p. 100). Moreover, legislation typically is not animated by a desire to recognize and assist private parties in coordinating their individual affairs; it is intended by the state to create and impose a new state of affairs on private citizens that would not emerge from voluntary interaction. For instance, you and I could enter into a contract for me to have you work at my shop. We could contract about the terms-wages, benefits, hours, and everything else-in a way that makes each of us happy and is mutually beneficial. Assume, now, that the legislature passes a law that prohibits you from working for any wage below a certain dollar amount. The very definition of a minimum wage is that I am not allowed to contract with you for less even if both of us believe the contract would be mutually advantageous. Thus, in this example, legislation is a barrier to private ordering and to mutually advantageous exchange. Rather than the law facilitating our exchange

institutional framework of default rules that permits parties to know and, if desired, to voluntarily contract around those rules to effectuate their subjective preferences.

5 This emergence of spontaneous order in law potentially implies some degree of competition among courts and judges. See Stringham and Zywicki (2011) and Zywicki (2003). 
and allowing us to pursue our desired ends, legislation becomes the vehicle for discoordination and an obstacle to the pursuit of our mutually advantageous plans. In turn, Leoni (a pioneer of public choice theory) observes that this outcome creates certain incentives in the legislative process for rent-seeking: "In this way, legislation has undergone a very peculiar development. It has come to resemble more and more a sort of diktat that the winning majorities in the legislative assembly impose upon the minorities, often with the result of overturning long-established individual expectations and creating completely unprecedented ones. The succumbing minorities, in their turn, adjust themselves to their defeat only because they hope to become sooner or later a winning majority and to be in the position of treating in a similar way the people belonging to the contingent majority today" (1991, p. 13).

It is this notion of the Roman law and the English common law emerging as a byproduct of individuals' private efforts to vindicate their rights that leads Leoni (presaging Hayek) to observe that law in this sense is something to be discovered, not something to be made: "Both the Romans and English shared the idea that the law is something to be discovered more than to be enacted and that nobody is so powerful in his society as to be in a position to identify his own will with the law of the land" (1991, p. 11)—unlike a legislature, or apparently now a president, who claims the power to make or unmake laws with the stroke of a pen.

\section{Discovering the Law}

What does Leoni mean by the notion that the Roman magistrates "discovered" the law instead of "making" it? He writes:

The Roman jurist was a sort of scientist: the objects of his research were the solutions to cases that citizens submitted to him for study, just as industrialists might today submit to a physicist or to an engineer a technical problem concerning their plants or their production. Hence, private Roman law was something to be described or discovered, not something to be enacted - a world of things that were there, forming part of the common heritage of all Roman citizens. Nobody enacted that law; nobody could change it by any exercise of this personal will. This did not mean absence of change, but it certainly meant that nobody went to bed at night making his plans on the basis of a present rule only to get up the next 
morning and find that the rule had been overturned by a legislative innovation. (1991, p. 83)

This attitude of judges as law "discoverers" rather than law "makers" thus speaks to a certain humility in lawmaking conducive to the preservation of liberty that distinguishes judges from legislators.

The difference between the short-term certainty of legislation and the long-term certainty of common law is crucial to Leoni's belief that in the long run, a system centered on legislation is fundamentally incompatible with a free society. Part of the problem lies in the practical realities of the political process: legislation responds to the demands of rent-seekers and other special-interest groups to oppress or plunder nonconsenting losers in the political process. The problem also has to do with the inherent instability of the legislative process and the relative predictability of the common-law process, properly understood. This public choice analysis of the legislative process contrasted with a law-and-economics analysis of the common-law process is Leoni's greatest contribution to jurisprudence. ${ }^{6}$

Leoni makes the unremarkable observation that for the free market to function effectively, private individuals need a stable legal framework in which to plan and to be confident that their plans will be carried through to fruition. Moreover, for individuals to be free from oppression, it is necessary for government to announce their rules in advance, so that individuals can know their permitted range of freedom (what is often, although imprecisely, referred to as the "rule of law"). This primacy of predictability and certainty has led many modern thinkers to advocate for greater legislation, as well as the need to spell out the rules in precise detail. In theory, legislation can promote predictability through detailed directions to private parties.

Leoni challenges the notion that simply because statutory law can be more precise in the short run, it is more predictable. He argues not only that it is common law, not legislation, that is more predictable, certain, and conducive to liberty and the rule of law, but that the superiority of the common law on this point derives from its unwritten nature and the "discovery" process of judges.

\footnotetext{
${ }^{6}$ Indeed, Leoni's insight predates Richard Posner's similar distinction in Economic Analysis of Law by over a decade. See Posner (2003, p. 532): "Although the correlation is far from perfect, judge-made rules tend to be efficiency-promoting while those made by legislatures tend to be efficiency-reducing."
} 
Understanding why Leoni (and Hayek later) believes the common law to be more certain and predictable-despite its unwritten characteristics-derives from recognizing that the common law is a conceptual system, as opposed to legislation, which is a verbal system of commands. What does that mean? The underlying "law" to be discovered, for both Leoni and Hayek, is a sense of shared concepts that emerge from this spontaneous collaboration among private litigants, judges, and citizens that give rise to a certain shared sense of law and justice. The underlying substantive notions of shared expectations of right and wrong, as well as the "artificial logic" of the common law, create legal concepts such as consideration in contract, duty and causation in tort, and rules of conveyance in property (Leoni 1991). While these underlying norms are always changing gradually and often imperceptibly, over time they are relatively constant; and when they do change, it is in a gradual and predictable manner that comports with individual expectations, even as those expectations may also change over time. Thus, the common law is a conceptual system in which the articulations of judicial decisions (and rulemaking as a byproduct) are verbal attempts to articulate the underlying concepts. Yet, it is the concepts of the common law that are the law, not the precise linguistic formulations of judges applying those concepts to particular disputes. Further, it is because the concepts that underlie the common law are stable and wellunderstood, Leoni says, that the common law, although lacking precise verbal formulations, is more predictable than legislation. Moreover, because this law exists outside the creation of judges, legislatures, or anyone else, it is largely insulated from rent-seeking and other distortions inherent in legislation.

Leoni's views on the law are distinct from those of modern thinkers, who, under the sway of legal positivism, have come to think of the precise verbal articulations by judges as being the law. Modern scholars thus analogize common-law judges to legislators who create law through their verbal commands. According to this understanding of the legal process, judicial opinions should be read like statutesthe verbal formulations should matter more than the unexpressed concepts that those verbal formulations are attempting to express.

Having contrasted the ideal forms of legislation and common law, Leoni also admits that this jurisprudential revolution has taken its toll on the common law, such that today's common law has taken on many of the unfortunate characteristics of legislation. He writes, "On the other hand, it cannot be denied that the lawyer's law or the 
judiciary law may tend to acquire the characteristics of legislation, including its undesirable ones, whenever jurists or judges are entitled to decide ultimately on a case" (1991, p. 24). Indeed, he refers to the fact that for at least the first millennium of the common law, there was no concept of binding precedent or "stare decisis" (i.e., that one ruling makes the law and is binding on subsequent courts) (1991, p. 86). ${ }^{7}$ Indeed, Leoni says that common-law judges were more like "spectators" observing what private citizens have created as their own law than "actors in the law-making process." He writes, "Private citizens were on the stage; common law was chiefly just what they commonly thought of as being law" (1991, p. 86). In this sense, judges were analogous to grammarians "epitomizing" the rules of language developed spontaneously by the people or a statistician "who makes records" describing the prices and quantities at which individuals trade in a market $^{8}$ (1991, p. 87).

Leoni singles out for specific criticism the establishment of "supreme courts" that can render definitive judgments binding on other courts and the resulting "imposition of the personal views of members of those courts, or of a majority of them, on all the other people concerned whenever there is a great deal of disagreement between the opinion of the former and the convictions of the latter" (1991, p. 24). Nevertheless, he argues that this bastardization of court processes into quasi-legislative outcomes is not an inevitable evolution of judicial lawmaking, but can be prevented with proper diligence and institutional design.

\section{Lawful Certainty}

Leaving aside the common law system of today and returning to Leoni's classical vision, he thus provides his great insight: a crucial distinction between what he calls the "short-run" certainty of the law, embodied in legislation, and the "long-run" certainty of the law promoted by the common law. So he writes, "While legislation is almost always certain, that is, precise and recognizable, as long as it is 'in force,' people can never be certain that the legislation in force today will be enforced tomorrow or even tomorrow morning. The legislation-centered legal system, while involving the possibility that

\footnotetext{
7 "There were so many courts of justice in England and they were so jealous of one another that even the famous principle of the binding precedent was not openly recognized as valid by them until comparatively recent times (Leoni 1991, p. 86). ${ }^{8}$ Hayek similarly analogizes the role of the judge in the common-law process to a grammarian or to prices in a market process. See Zywicki and Sanders (2008).
} 
other people (the legislators) may interfere with our interactions every day, also involves the possibility that they may change their way of interfering every day. As a result, people are prevented not only from freely deciding what to do, but from foreseeing the legal effects of their daily behavior" (1991, p. 10).

Moreover, because legislation changes unpredictably and largely arbitrarily in response to shifting political coalitions, changes in legislation are often abrupt, discontinuous, and illogical, in that their justification derives not from their reason or good sense, but simply the relative influence of competing interest groups and unintended consequences.

As a result, private citizens cannot easily project the future direction of legislative change and plan accordingly. Indeed, the unpredictable and unprincipled nature of legislative change is a defining characteristic of lawmaking in recent years. Even dulyenacted legislative mandates (such as deadlines imposed by the Affordable Care Act) have been suspended or waved aside by the president (and presumably could be reinstated equally arbitrarily) by processes as irregular as blog posts or press conferences announcing that certain laws simply would not be followed.

Yet, the situation today is even worse than Leoni feared. While Leoni expressed concern that legislators might "change their way of interfering every day" (1991, p. 10), could he have imagined today's world, in which the president of the United States asserts the authority to write or rewrite any law and to effectively retroactively veto laws by refusing to enforce them or defend them in court when challenged? Not only can legislatures potentially change the law daily, but some days, the law can seem to vary almost hourly.

Fifty years ago, Leoni posed the "radical" question of whether freedom could survive in a system centered on and almost completely associated with a legal system premised on legislation (1991, p. 11). What would Leoni think of the current system, one of lawmaking not only by legislation-which itself has unleashed an orgy of unprecedented special-interest rent-seeking-but one degraded to lawmaking via blog posts and press releases? While he certainly would be dismayed - as is any person concerned about the rule of law and constitutional government-I suspect that Leoni would not necessarily be surprised. He foresaw, fifty years ago, the principles underlying the path we were on, and he pointed out the direction in which we were headed. He warned us that our descent from the rule of law is inexorable. 
If we return to Leoni's opening question-Is individual freedom compatible in principle with our present system of legislation as law? - we must acknowledge that this question has become even more relevant and pressing today than it was fifty years ago.

\section{References}

Barry, Norman. 1982. "The Tradition of Spontaneous Order." Literature of Liberty, 5(2): 7-58.

De Alessi, Louis, and Robert J. Staaf. 1989. "Subjective Law in Contract Law." Journal of Institutional and Theoretical Economics, 145(4): 561-77.

De Alessi, Louis, and Robert J. Staaf. 1991. "The Common Law Process: Efficiency or Order?” Constitutional Political Economy, 2(1): 107-26.

Hayek, Friedrich. 1944. The Road to Serfdom. Chicago: University of Chicago Press.

Hayek, Friedrich. 1960. The Constitution of Liberty. Chicago: University of Chicago Press.

Hayek, Friedrich. 1968 [2004]. "Bruno Leoni, the Scholar." Il Politico, 33(1): 21-25.

Hayek, Friedrich. 1973. Law, Legislation and Liberty, Volume 1: Rules and Order. Chicago: University of Chicago Press.

Kemp, Arthur. 1990. Foreword to Freedom and the Law, by Bruno Leoni. Expanded 3rd ed. Indianapolis: Liberty Fund.

Leoni, Bruno. 1961 [1972]. Freedom and the Law. Fairfax, VA: William Volker Fund, under the sponsorship of the Institute for Humane Studies.

Leoni, Bruno. 1991. Freedom and the Law, expanded 3rd ed. Indianapolis: Liberty Fund.

Liggio, Leonard P., and Tom G. Palmer. 1988. "Comment: Freedom and the Law: A Comment on Professor Aronson's Article." Harvard Journal of Law and Public Policy, 11(3): 713-25.

Posner, Richard. 2003. Economic Analysis of Law, 6th ed. New York: Aspen.

Shearmur, Jeremy. 1996. Hayek and After: Hayekian Liberalism as a Research Programme. London: Routledge Studies in Social and Political Thought.

Stringham, Edward Peter, and Todd J. Zywicki. 2011. "Hayekian Anarchism." Journal of Economic Behavior and Organization, 7: 290-301.

Zywicki, Todd J. 2003. "The Rise and Fall of Efficiency in the Common Law: A Supply-Side Analysis." Northwestern Law Review, 97: 1551-1634.

Zywicki, Todd J., and Anthony B. Sanders. 2008. "Posner, Hayek, and the Economic Analysis of Law." Iowa Law Review, 93: 559-604. 